Adrie Winkelaar

Coatings Basics 
Cover: Evonik Degussa Coatings \& Colorants - Dieter Debo, Infracor, Marl/Germany

Bibliographische Information der Deutschen Bibliothek

Die Deutsche Bibliothek verzeichnet diese Publikation in der Deutschen Nationalbibliographie; detaillierte bibliographische Daten sind im Internet über http://dnb.ddb.de abrufbar.

\author{
Adrie Winkelaar \\ Coatings Basics \\ Hannover: Vincentz Network, 2009 \\ (European Coatings Tech Files) \\ ISBN 3978-3-7486-0220-0
}

(C) 2009 Vincentz Network GmbH \& Co. KG, Hannover

Vincentz Network, P.O. Box 6247, 30062 Hannover, Germany

This work is copyrighted, including the individual contributions and figures.

Any usage outside the strict limits of copyright law without the consent of the publisher is prohibited and punishable by law. This especially pertains to reproduction, translation, microfilming and the storage and processing in electronic systems. The information on formulations is based on testing performed to the best of our knowledge.

Please ask for our book catalogue

Vincentz Network, Plathnerstr. 4c, 30175 Hannover, Germany

Tel. +49 511 9910-033, Fax +49 511 9910-029

E-mail: books@european-coatings.com,www.european-coatings.com

Layout: Maxbauer \& Maxbauer, Hannover, Germany

ISBN 978-3-7486-0220-0 
European Coatings Tech Files

Adrie Winkelaar

\section{Coatings Basics}

